\title{
The Tea Industry and a Review of Its Price Modelling in Major Tea Producing Countries
}

\author{
R P Dayani Gunathilaka ${ }^{1} \&$ Gurudeo A Tularam ${ }^{2}$ \\ ${ }^{1} \mathrm{PhD}$ Candidate, School of Environment, Griffith University, South East Queensland, Australia \\ ${ }^{2}$ Senior Lecturer in Mathematics and Statistics, Griffith Sciences (ENV, EFRI), Griffith University, South East \\ Queensland, Australia \\ Correspondence: Gurudeo A Tularam, Senior Lecturer in Mathematics and Statistics, Griffith Sciences (ENV, EFRI), \\ Griffith University, South East Queensland, Australia.
}

Received: July 26, 2015

Accepted: August 6, 2015

Online Published: January 26, 2016

doi:10.5430/jms.v7n1p21

URL: http://dx.doi.org/10.5430/jms.v7n1p21

\begin{abstract}
The global production and consumption of tea has been steadily increasing over the past decades. The tea industry has become a significant contributor to the economies of producing countries such as Kenya, Sri Lanka, India and China. Apart from its economic importance, the environmental and social importance of tea production has been recognised in the literature. However the industry is confronted by a number of challenges. These challenges include resource constraints, competition for land, unavailability of adequate labour, and climate change, as is noted in this article. All of the major tea producing countries have identified climate change as being a major challenge. Therefore, identification of the appropriate methods for modelling tea prices by incorporating a group of interacting time series variables such as price, production and weather variables to explain the dynamic relationships among these time series is important for producers. This article reviews and examines the approaches used to model tea price. In particular, various time series techniques are reviewed. The analysis clearly shows that quite a number of studies have been done on tea pricing. We found that VAR techniques have the ability to model the non-structural relationship of tea price alongside other time series variables which are endogenous and exogenous in nature. This paper also contributes to the existing literature by summarising the research undertaken on tea pricing to date.
\end{abstract}

Keywords: drivers of tea price, modelling, Sri Lanka

\section{Introduction}

The global market for tea is currently estimated to be around US\$ 15.4 billion (2013), in terms of production value (World Tea News, 2014) and US\$ 40.7 billion in terms of retail value (Euromonitor International, 2014). World tea production has increased significantly over the past two decades (Figure 1). This may be due to several reasons such as increasing population sizes, the increasing social acceptance of tea as the drink of choice, an increase in the area of tea cultivation, improved varieties of tea cultivation by selective breeding (cultivars), advanced technology and improved cultivation practices (Majumdar et al, 2012). 


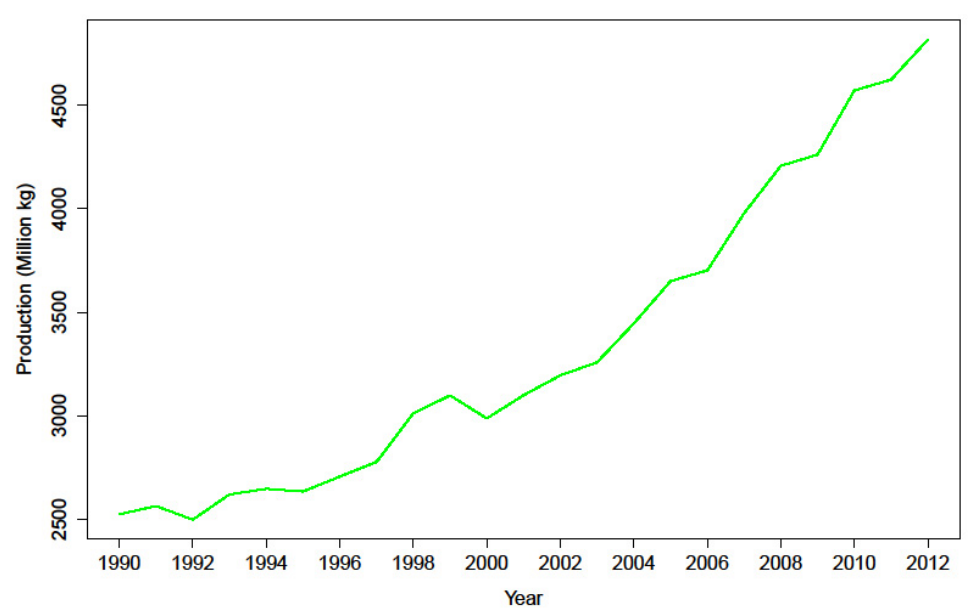

Figure 1. Global tea production 1990-2012 (million kg)

Source: FAOSTAT

While tea is an export commodity, it is not exported by all producing countries. Throughout the world, the export of tea increased by an average of $2.31 \%$ per annum over the period 1991-2000, rising from 1078.17 million $\mathrm{kg}$ to 1324.65 million $\mathrm{kg}$. A similar trend and a 3.4\% average annual growth rate were observed from 2001 to 2012 when exports increased from 1400.55 million $\mathrm{kg}$ to 1740 million $\mathrm{kg}$ (Figure 2).

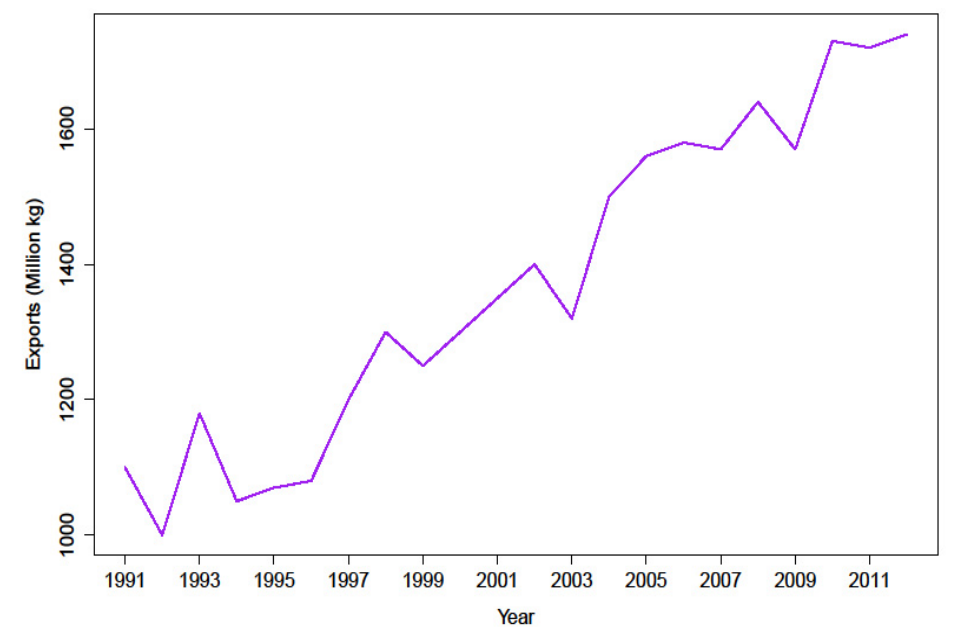

Figure 2. World tea exports 1991-2012

\section{Source: FAOSTAT}

China, India and Sri Lanka are the major tea producing countries in Asia, while Kenya, Malawi, Rwanda, Tanzania and Uganda are the major tea producers in Africa. There are also minor producing countries such as Nepal, Peru, Papua New Guinea, and Zimbabwe. Altogether there are 34 tea producing countries throughout the world (FAOSTAT, 2014). As Figure 3 shows, most of the major producers are located in Asia, possibly because the cultivation of tea originated in South East Asia (Paul et al., 1997; Hicks, 2001; Rogers, 2007; Alkan et al., 2009). 


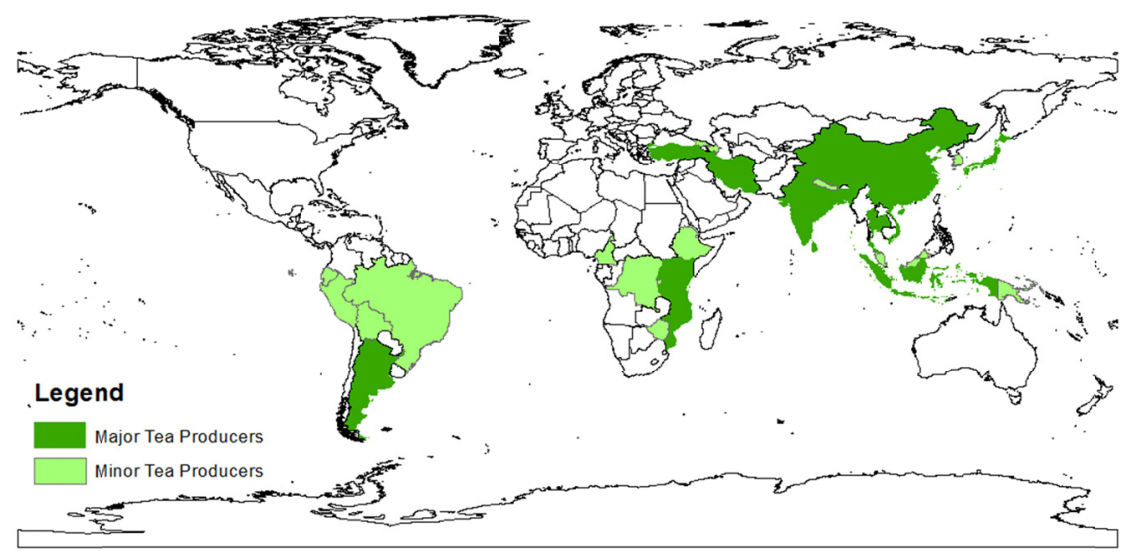

Figure 3. The world's tea producing countries

The aims of this paper are (1) to briefly summarise the economic and social significance of the tea industry, (2) to review the literature on tea price modelling, (3) to identify the extent to which climate change variables have been included in tea price modelling, and (4) to examine how current tea price models could be improved by incorporating climate change impacts.

The paper is organized as follows. In Section 2, we describe the current status of the world tea industry in general and the Sri Lankan tea industry in particular. Section 3 reviews the literature on tea price modelling. A discussion of future directions for the modelling of the tea price is presented in Section 4, before concluding the paper with a brief summary.

\section{Current Status of the World Tea Industry}

\subsection{Major Producers and Their Market Share}

China, India, Kenya and Sri Lanka are the four biggest tea producers in the world (FAOSTAT, 2012). China's production share of tea is $28 \%$ but its market share in the global sphere is $18 \%$, since domestically, China consumes about $70 \%$ of the tea it produces. Over the past decade, China has shown an increase in tea consumption (Hicks, 2009). The employment opportunities provided by the industry record that up to 8 million workers in China are employed in this industry (Groosman, 2011).

India is the second largest producer of tea, contributing a $25 \%$ share of production and a market share of exports of about $12 \%$. In addition to exporting, India also consumes much of its own tea domestically. This internal consumption has increased over the years with local production failing to fulfil domestic demand (Pajankar and Thakare, 2009). The forecasts show that there will be a rise in Indian domestic consumption from 1.118 metric tonnes in 2011 to 1.365 metric tonnes in 2015 (Brouder et al., 2012). Moreover, the tea industry is also India's second largest employer, providing livelihoods for over 3.5 million people (Tea Board of India, 2014).

Though Kenya falls in third place with a 9\% share of global production, it is the largest exporter of tea in the world. The export market share of Kenyan tea is $24 \%$ by volume and Kenyan export earnings are about $26 \%$ of the world's total by value. The contribution to the Kenyan agricultural sector's GDP is about $11 \%$, and over $60 \%$ of this production is contributed by small holders, often farming less than 1 acre of cultivated land. Therefore the tea industry is one of the largest private sector employers in the country (Majumdar et al., 2012; Monroy et al., 2013; Tea Board of Kenya, 2013).

Tea is Sri Lanka's foremost plantation agricultural export and is a primary source of foreign exchange (Wijeratne, 1996; Ganewatta et al., 2005; Central Bank of Sri Lanka, 2013). The tea sector has contributed $15 \%$ to the sum total of Sri Lankan foreign exchange earnings in the year 2013 (Ganewatta et al., 2005; Central Bank of Sri Lanka, 2013). The tea sector provides a livelihood for about $30 \%$ of state sector employees, the majority of whom are residential workers on tea plantations (Wijeratne, 1996; Sivaram, 2000). The tea small holding sector also contributes considerable employment opportunities in this country. Accordingly, the Sri Lankan tea industry provides employment for $10 \%$ of the population (Wijeratne, 1996; Ganewatta et al., 2005; FAO, 2012). In 2012, Sri Lanka 
produced about 330 million $\mathrm{kg}$ of tea, ( $8.5 \%$ of the world's tea production) and accounted for $18.3 \%$ of global exports (Hettiarachchi and Banneheka, 2013; Central Bank of Sri Lanka, 2013). More than $90 \%$ of the tea produced in Sri Lanka is for the export market (Hettiarachchi and Banneheka, 2013; Ganewatta et al., 2005; Central Bank of Sri Lanka, 2013).

\subsection{Economic and Social Significance of the Tea Industry}

Next to water, tea is the most popular and the cheapest beverage in the world (Kondo et al., 2004; Rahman, 2007; Hilal and Engelhardt, 2007; Alkan et al., 2009; Vernarelli and Lambert, 2013; Khan and Mukhtar, 2013; Gramza-Michalowska, 2014). Increasing numbers of people are enjoying tea in many different situations from formal meetings to informal gatherings. Tea originates from the younger portions of the shoots of Camellia sinensis, an evergreen shrub or small tree (Hilal and Engelhardt, 2007; Rahman, 2007; Song et al., 2012; Khan and Mukhtar, 2013). Different types of tea are produced based on levels of oxidation during the manufacturing process. Black tea is fully oxidised, green tea is non-oxidised, while oolong tea is semi oxidised (Hilal and Engelhardt, 2007; Song et al., 2012).

People of all ages enjoy tea as a beverage (Rahman, 2007; Voung, 2014), and about two thirds of the world's population drinks tea in some form or other every day their as "morning drink" (Nasir and Shamsuddoha, 2011). Tea has been gaining popularity due to rising consumer awareness of its health benefits and its medicinal value (Gramza-Michalowska, 2014; Tounekti et al., 2013; Khan and Mukhtar, 2013; Lambert, 2013; de Godoy, 2013). As a result, tea is sold in most supermarkets, health and natural food stores, drug stores, mass merchandisers and in tea and coffee rooms throughout the world. New brands of tea and tea products are appearing weekly around the world and pharmaceutical products based on tea are constantly being developed.

The economic importance of the tea industry is manifold for the tea producing countries. The industry provides a vital source of export earnings for tea exporting countries (Wijeratne, 1996; Majumder et al., 2012; Pajankar and Thakare, 2009; Wachira and Kamunya, 2005; Ganewatta et al., 2005; Dang and Lantican, 2011; Mwaura and Muku, 2007; Sivaram, 2000; Alkan et al., 2009). A large proportion of these nations' populations rely on the tea industry for employment (Wijeratne, 1996; Majumder et al., 2012; Pajankar and Thakare, 2009; Wachira and Kamunya, 2005; Ganewatta et al., 2004; Dang and Lantican, 2011; Mwaura and Muku, 2007; Sivaram, 2000; Alkan et al., 2009). Apart from the economic benefits for the producers, tea plantations also deliver other important ecosystem services such as carbon sequestration, soil fertility protection and water conservation (Xue et al., 2013; Li et al., 2011).

Indeed, the well-being of millions of people across the world depends on tea as it is an antioxidant (Yang et al., 2009). The social importance of tea production is also significant in the vast networks of people who conduct their social gatherings and official meetings using the drinking of tea as part of the fabric of their gatherings. It is not just the tea consumers who benefit, but also growers, pickers, suppliers, traders and sellers connected through business operations.

\subsection{Challenges Facing the Tea Industry}

The tea sector has had to confront unprecedented challenges over the past few decades. The development of new business models, trading and investment in tea are vital to sustain the industry's competitive advantage over other beverage commodities (Brouder et al., 2013). There are signals in technology, markets and management of the tea industry that demonstrate how the industry ought to transform in the future. The development of composite products such as "ready-to-drink" tea and other types of "value-added" tea are signs of transformation in the industry (Ganewatta et al., 2005; Brouder et al., 2013). In terms of the tea market, moving from the existing physical auction system towards the online trading of tea has been trialled experimentally.

Tea is a labour intensive crop and the ready availability of labour for picking and processing is essential. With demographic changes, the youth population in rural areas tends to migrate to urban areas for better employment opportunities (Van der Wal, 2008; Illukpitiya et al., 2004; Kingsolver, 2010; Madamombe, 2013). This situation has been compounded by the introduction of mechanization that has led to job losses in field operations, even though mechanization has aided the production process.

The changes in the wage and welfare structure of tea plantation workers are another challenge for the sector. Traditionally the wages of tea plantation workers have been low, although they may meet the minimum standards of some producing countries. This can be controversial, but often plantation workers are provided with welfare in kind such as housing, health facilities, child care and education. Whilst in-kind benefits may help balance the wage structure of plantation workers, wage rates in some producing countries do need attention (Brouder et al., 2013; Van der Wal, 2008; Groosman, 2011). Modern consumers are showing concern about unethically produced goods, and this is encouraging for the expanding demand for ethically produced tea products (Ethical Tea Partnership, 2012). 
Nonetheless, there is a need for tea producing countries to comply with environmentally sustainable production methods and socially acceptable employment conditions for the plantation workers. The expanding tea industry requires more land for increasing production, but a decrease in suitable tea growing lands caused by climate change has also been noted worldwide (Brouder et al., 2013).

In addition to the above challenges, the potential effect of climate change has become an important issue for most of the major tea producing countries. One of the key concerns noted by the Food and Agriculture Organization (FAO) was the impact of climate change on tea production (FAO, 2014). An FAO working group on climate change was formed in 2012. Its aims were to develop climate databases, models and an impact assessment as well as a decision support system framework for identifying adaptation strategies. There have been a number of projections of the effects of climate change in tea producing countries. For example, it is projected that some of the tea producing regions in Kenya are now becoming less suitable due to increasingly erratic rainfall, increasing temperatures and higher incidence of hail (Ethical Tea Partnership, 2011; FAO, 2014). The discussions about climate change concluded that extreme weather events in the future would influence the production of tea (Ethical Tea Partnership, 2011; FAO, 2014).

India is one of the largest tea producers in the world and more than half of their national production comes from the north eastern region (Roy, 2011). The FAO working group investigating the effect of climate change on tea production notes that total annual precipitation shows a slowly decreasing trend in this region (Figure 4) (FAO, 2014). This erratic pattern of rainfall has resulted in drought and flood conditions in tea fields. Moreover, during the past 88 years the minimum temperature has shown an increasing trend. As noted by the FAO, the minimum temperature has increased by $1.4{ }^{\circ} \mathrm{C}$ over the period of 1925 to 2013 (Figure 5) (FAO, 2014). During the past 30 years, daily temperatures of more than $30{ }^{\circ} \mathrm{C}$ have been reported frequently. Such temperatures are not suitable for the growth of tea bushes.

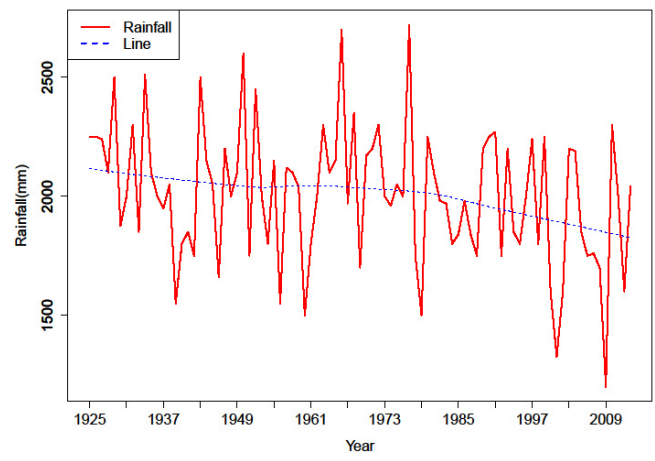

Figure 4. Annual rainfall pattern north eastern India (1925-2013)

Source: FAO, 2014

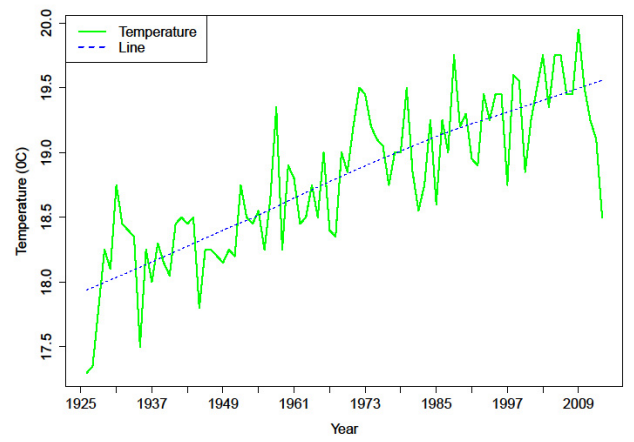

Figure 5. Annual average minimum temperature at Tocklai, Jorhat, Assamin, India (1925-2013)

Source: FAO, 2014 
Trend analyses of rainfall have been undertaken for various agro-ecological zones in Sri Lanka (FAO, 2014). These analyses have shown that most tea growing regions have received low intensity rainfall during the past two decades (Figure 6) (FAO, 2014). According to climate change projections, Sri Lanka will experience more frequent extreme weather events such as an increase in the temperature and more intense rainfall (FAO, 2014). The possibility of a $10 \%$ increase in the length of both the dry and the wet seasons per year in the main tea planting districts has been noted. Also predicted was an increase in mean temperature and the likelihood of adverse effects in most tea growing areas (Wijeratne et al., 2007). Wijerathne (1996) suggests that some of the likely adverse consequences of climate change for the tea growing industry are drought damage, increased occurrences of pest and diseases and soil losses in tea fields.

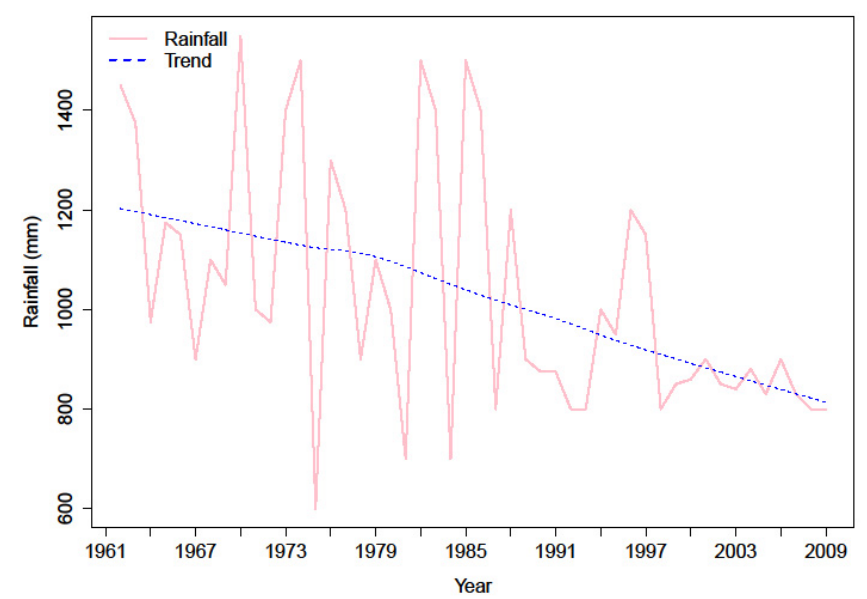

Figure 6. Rainfall pattern during $1^{\text {st }}$ inter-monsoon and south-west monsoon in the up-country intermediate 1 (IU1) tea growing region in Sri Lanka (1961-2009)

Source: FAO, 2014

It is evident that there are numerous challenges confronting the tea industry. Analysis of the relevant literature has made it clear that these challenges are related to production, marketing and consumption, each with different intensity. However, it is becoming increasingly obvious that major tea producing countries have highlighted the effects of climate change as being one of the critical challenges which they will have to confront in the future.

\section{Price Modelling Related to the Tea Industry}

World tea prices (US \$ per kg) from 1989 to 2011 are depicted in Figure 7. The price of tea fluctuated between 1989 and 2005, before escalating significantly from 2006 to 2009, rising from US $\$ 1.6$ per $\mathrm{kg}$ to $2.85 \mathrm{per} \mathrm{kg}$; around an $80 \%$ increase. The reasons for this robust growth have been explained by the FAO's Committee on Commodity Problems. Some of the explanations given are:

- improved supply and demand balance;

- $\quad$ for the first time on record, world tea consumption exceeded production in2009, 2010 and 2011;

- depreciation of the US $\$$ and increased transportation costs due to high oil prices (FAO, 2012 CCP:TE 12/CRS 7). 


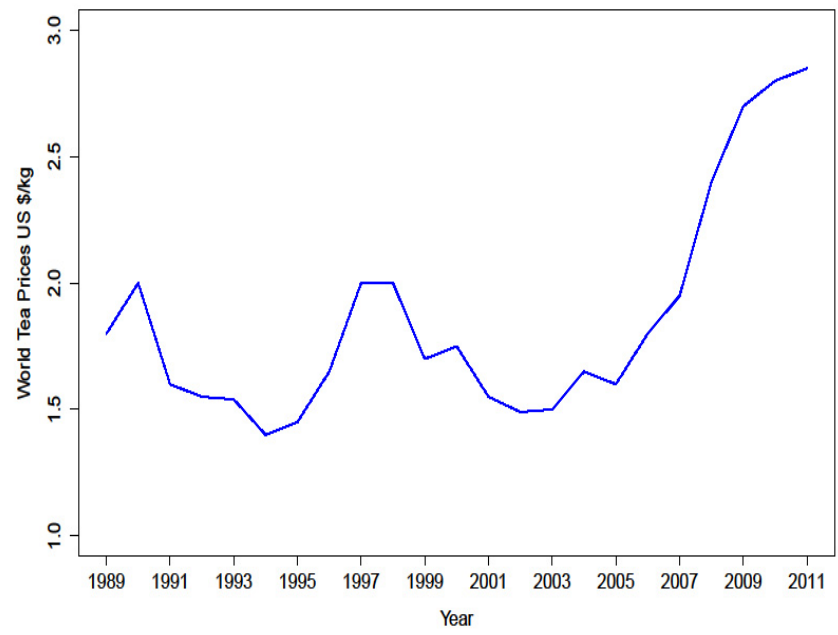

Figure 7. World tea prices (1989-2011)

(Source: FAOSTAT)

Sapsford and Varoufakis (1987) employed a seasonal auto-regressive integrated moving average (SARIMA) model to examine historical monthly tea prices from January 1958 to April 1973 using 184 observations. The general model for ARIMA is:

$$
\Delta^{d} y_{t}=\delta+\theta_{1} \Delta^{t} y_{t-1}+\theta_{2} \Delta^{d} y_{t-2} \ldots+\theta_{p} \Delta^{d} y_{t-p}+e_{t}+\alpha_{1} e_{t-1}+\alpha_{2} e_{t-2} \ldots+\alpha_{p} e_{t-p}
$$

similar auto regressive (AR) models had been used previously for modelling cocoa prices (Beenstock and Bhansali 1980). However, Sapsford and Varoufakis used the model building strategy of Box and Jenkins (1970), and found that the autocorrelation and partial autocorrelation functions of the differenced series of monthly tea prices indicated that ARIMA was a more appropriate model for forecasting tea prices, outperforming the AR(2) and random walk models used in Beenstock and Bhansali's study. This was due to the non-normality of residuals and the AR (2) model's failure to anticipate "turning points".

Vickner and Davies (2002) estimated the strategic price response of herbal and black tea using a vector error correction (VEC) model. The typical model can be characterized as below.

$$
\begin{gathered}
\Delta y_{1 t}=\pi_{11}+\pi_{12} \Delta y_{1, t-1}+\pi_{13} \Delta y_{2, t-1}+\pi_{14} \Delta y_{1, t-2}+\pi_{15} \Delta y_{2, t-2}+u_{1 t} \\
\Delta y_{2 t}=\pi_{21}+\pi_{22} \Delta y_{1, t-1}+\pi_{23} \Delta y_{2, t-1}+\pi_{24} \Delta y_{1, t-2}+\pi_{25} \Delta y_{2, t-2}+u_{2 t} \\
\Delta y_{1 t}=\pi_{11}+\pi_{12} \Delta y_{1, t-1}+\pi_{13} \Delta y_{2, t-1}+\pi_{14} \Delta y_{1, t-2}+\pi_{15} \Delta y_{2, t-2}+\delta_{1} e c_{t-1}+v_{1 t} \\
\Delta y_{2 t}=\pi_{21}+\pi_{22} \Delta y_{1, t-1}+\pi_{23} \Delta y_{2, t-1}+\pi_{24} \Delta y_{1, t-2}+\pi_{25} \Delta y_{2, t-2}+\delta_{2} e c_{t-1}+v_{2 t}
\end{gathered}
$$

The error correction term is characterised by $e c_{t}=y_{t 2}-\beta y_{t 1}$

Vickner and Davies used Johanson's full information maximum likelihood ratio test to identify co-integration between the black and herbal tea markets, and also among various firms in the black tea market.

Dharmasena (2003) investigated the price mechanisms relating to black tea. He analysed weekly price data on black tea from seven major markets in the world, using vector autoregressive (VAR) methods, incorporating directed acyclic graphs, impulse response functions and forecast error decomposition analyses. By these methods Dharmasena found that the Sri Lankan and Indonesian black tea markets were noted to be price leaders, while the Kenyan tea market acted as an information sink. Dharmasena's study also found that random walk forecasts of tea pricing outperformed VAR based forecasts.

Rahman (2007) investigated the impact of tea price on supply responses of tea in Bangladesh. He analysed 12 years annual time series data of tea production and prices using the cobweb supply model. The ordinary least squares estimation method was deployed by correcting the sample for autocorrelation and multi-collinearity using the 
Cochrane-Orcutt iterative procedure. In addition, this study estimated the supply price elasticity of tea. Rahman's results showed the supply price elasticity of tea to be 1.1, indicating that the quantity supplied changes at a greater rate than variability of price. However, this study was unable to incorporate important variables such as technical changes and weather parameters into the estimated model.

Paul (2008) used data mining techniques to predict tea price using a hedonic pricing approach based on sensory assessments and biochemical information. He used Wright et al.'s (2002) data and first explored the strength of the statistical association of biochemical parameters with sensory assessments and price, using ANOVA with methods of moments (MM) estimates. The results showed a significant association of all the quality attributes with the realised price, with the exception of colour. Paul used multivariate adaptive regression splines (MARSplines) over a Box-Cox transformation because the relationships were non-linear and exact interaction effects between the sensory attributes were not known. This appears to be the first study which has attempted to construct a hedonic price function for tea.

Fernando et al. (2008) also used data mining techniques to analyse the Sri Lankan tea industry. They examined the trends of production, exports and price for all three elevations (low, medium and high). An autoregressive tree model (ART) in an SQL server was used in this study. Their results indicated a strong linear correlation (0.993) between production and exports of tea, proving that if more tea is produced, more can be exported. Fernando et al. found the auction prices in June-July to be lower than in the other periods of the year. Their analysis also found that auction price has no relationship with production volume. Cluster analysis for the production and price indicated that low grown tea was the most influential contributor to price. Their results showed a continuous increase in tea exports.

Dang and Lantican (2011) analysed the vertical integration of Vietnam's tea market to identify tea price behaviour. They analysed the degree of market integration at different levels of the marketing chain, namely at producer, processor, exporter and retailer level. Dang and Lantican used a VEC model and the law of one price (LOP) test using Johansen's framework (1990). In addition, they researched the causal effects of price series between each market level using bi-variate autoregressive distributed lags (ADL) tests and Granger causality. The results showed that the producer price and the processor price were highly co-integrated for the black tea market. Also, the retail market price was significantly correlated with producer prices in the green tea marketing channel. Moreover, the retail price of tea was found to have a unidirectional causal effect on the processor price for both black tea and green tea. Therefore the local retail market was found to be an important factor in export price volatility in the Vietnamese tea market.

Viknesh (2011) used VAR, VEC, SARIMA and multiplicative decomposition to develop models for forecasting Sri Lankan tea prices. This study has used the prices of high, medium and low grown tea as endogenous variables. Viknesh's results showed that VAR (2) delivered better prediction capability than univariate models.

Aponsu and Jayasundara (2012) used polynomial regression models to forecast Colombo tea auction prices, with a time index comparing the performance of linear, quadratic and cubic forms. They found that the cubic regression model was the most appropriate for tea price prediction, achieving a model fit of $91.3 \%$. The model can be represented as:

$$
y=a_{0}+a_{1} x+a_{2} x^{2}+a_{3} x^{3}+\cdots+a_{n} x^{n} .
$$

Hettiarachchi and Banneheka (2013) used time series regression with generalized least squares and artificial neural network (ANN) approaches for forecasting tea auction prices. They performed one-month-ahead forecasts for tea auction prices in Colombo, Kolkata, Cochin, Guwahati, Chittagong, Mombassa and Jakarta. A Box-Cox transformation was used to deal with non-normality. Their results indicated a significant positive correlation between prices at the Colombo auction and those at the other auction centres. Moreover, they compared the forecasting performance of both models and found that the ANN approach performed slightly better than the time series regression approach. However, they were not able to validate their ANN due to the unavailability of weekly tea prices at the auction centres, with the exception of Colombo.

Krishnarani (2013) examined the effect of outlier observations in tea price modelling. Indian tea prices were analysed using an ARIMA model. Krishnarani's study also searched for the presence of additive and innovational outliers using the methodologies of Box et al. (2009) and Louni (2008). Krishnarani concluded that the presence of outliers in the price series could be due to variation in climatic variables such as high rainfall, drought and pest outbreaks.

Table 1 summarizes the related literature on different approaches used for tea price modelling. A brief analysis of the models used by the different authors is also included. 
Table 1. Summary of the tea price modelling techniques in the literature

\begin{tabular}{|c|c|c|}
\hline $\begin{array}{l}\text { Modelling } \\
\text { technique }\end{array}$ & Authors & Review \\
\hline ARIMA & $\begin{array}{l}\text { Sapsford \& Varoufakis } \\
\text { (1987) } \\
\text { Krishnarani (2013) }\end{array}$ & $\begin{array}{l}\text { There seems to be general agreement that ARIMA is a better } \\
\text { technique than AR for forecasting price. Present and lagged prices } \\
\text { were used as the explanatory variables for modelling tea prices. } \\
\text { Although recent work by Krishnarani (2013) viewed the volatility } \\
\text { of the tea prices in terms of variations of rainfall, drought and pest } \\
\text { outbreaks, climate variables or pest and disease occurrences have } \\
\text { not yet been included as driving variables in econometric } \\
\text { modelling of tea prices. }\end{array}$ \\
\hline $\begin{array}{l}\text { Polynomial } \\
\text { regression }\end{array}$ & $\begin{array}{l}\text { Aponsu \& Jayasundara } \\
\text { (2012) }\end{array}$ & $\begin{array}{l}\text { Aponsu \& Jayasundara (2012) used polynomial regression for } \\
\text { forecasting tea prices. The time index of tea prices were used as } \\
\text { the explanatory variables }\end{array}$ \\
\hline Data mining & $\begin{array}{l}\text { Paul (2008) } \\
\text { Fernando et al. (2008) }\end{array}$ & $\begin{array}{l}\text { Paul (2008) incorporated sensory assessment scores and } \\
\text { biochemical parameters of tea in price modelling. Fernando et al. } \\
\text { used cluster analysis followed by time series analysis for } \\
\text { forecasting tea prices. They suggested future research regarding } \\
\text { correlations between tea marketing and prices as a better } \\
\text { approach for forecasting. }\end{array}$ \\
\hline VAR & $\begin{array}{l}\text { Vickner \& Davies (2002) } \\
\text { Dharmasena (2003) } \\
\text { Dang \& Lantican (2011) } \\
\text { Viknesh (2011) }\end{array}$ & $\begin{array}{l}\text { Vickner \& Davies (2002), Dharmasena (2003), Dang \& Lantican } \\
\text { (2011) and Viknesh (2011) studied historical tea prices using } \\
\text { VAR models for forecasting. Early work by Dharmasena (2003) } \\
\text { compared the forecasting performance of VAR and random walk } \\
\text { models and found that the random walk approach outperformed } \\
\text { VAR. However, findings reported by Vicknesh (2011) differ from } \\
\text { those of Dharmasena (2003). Dang \& Lantican (2011) identified } \\
\text { co-integration between producer and processor levels using a } \\
\text { VEC model with Granger causality. Vickner \& Davies (2002) } \\
\text { also employed VAR techniques in identifying co-integration } \\
\text { between the black and herbal tea industries. }\end{array}$ \\
\hline ANN & $\begin{array}{l}\text { Hettiarachchi \& } \\
\text { Banneheka (2013) }\end{array}$ & $\begin{array}{l}\text { Hettiarachchi \& Banneheka (2013) appeared to be the first to use } \\
\text { the ANN approach for tea price modelling. Their study was based } \\
\text { on findings of Dharmasena's (2003) work. However, } \\
\text { Hettiarachchi \& Banneheka (2013) obtained slightly improved } \\
\text { performance by using the ANN method compared to time series } \\
\text { regression methods. }\end{array}$ \\
\hline
\end{tabular}

The modelling techniques used for tea price modelling in the literature can be divided into three main categories: regression; time series and other. Regression techniques use time index and prices of other auction centres as the explanatory variable to model Colombo auction prices. Of the time series techniques, ARIMA models use current and lagged price terms as the explanatory variables, whereas VAR techniques use price series from different tea markets and from different types of tea. VAR techniques are thus able to model dynamic multi-variate time series. Amongst the 'other' approaches, ANNs quantitative and qualitative approaches use only historical price series as input data. In contrast, data mining uses mainly non-ratiometric data for modelling tea prices. Krishnarani (2013) appears to be the first to suggest that climate could affect tea price volatility. However, Krishnarani's study did not incorporate climate variables in its modelling. 
Table 2 indicates the variables used in time series approaches for tea price modelling.

Table 2.Variables used in different time series tea price modelling techniques

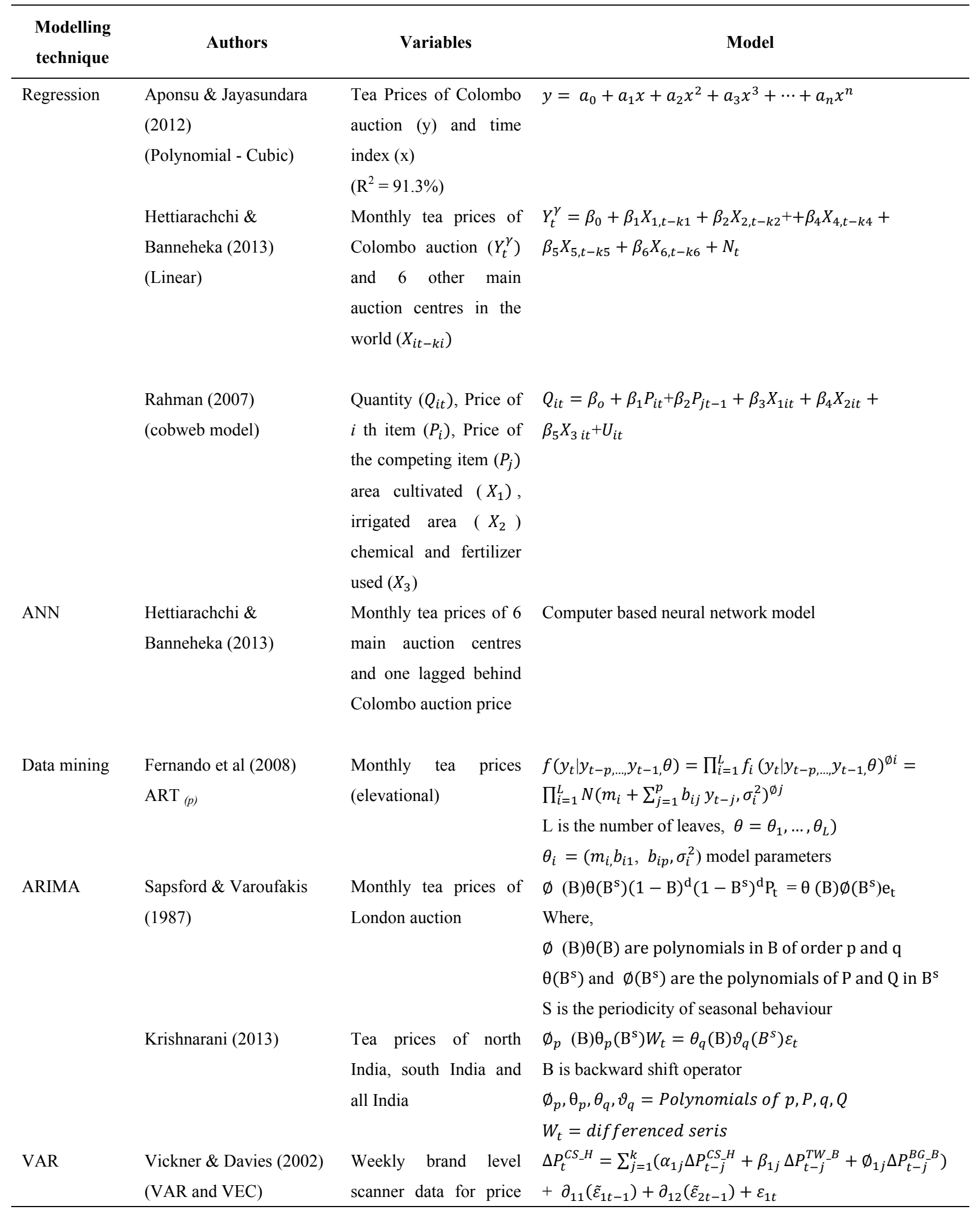


and expenditure for

three brands of tea in

black and herbal tea $\Delta P_{t}^{T W_{-} B}=\sum_{j=1}^{k}\left(\alpha_{2 j} \Delta P_{t-j}^{C S_{-} H}+\beta_{2 j} \Delta P_{t-j}^{T W_{-} B}+\emptyset_{2 j} \Delta P_{t-j}^{B G_{-} B}\right)$

$+\partial_{21}\left(\tilde{\varepsilon}_{1 t-1}\right)+\partial_{22}\left(\tilde{\varepsilon}_{2 t-1}\right)+\varepsilon_{2 t}$

$\Delta P_{t}^{B G_{-} B}=\sum_{j=1}^{k}\left(\alpha_{3 j} \Delta P_{t-\bar{j}}^{C S_{-} H}+\beta_{3 j} \Delta P_{t-j}^{T W_{-} B}+\right.$

$\left.\emptyset_{3 j} \Delta P_{t-j}^{B G_{-} B}\right)+\partial_{31}\left(\tilde{\varepsilon}_{1 t-1}\right)+\partial_{32}\left(\tilde{\varepsilon}_{2 t-1}\right)+\varepsilon_{3 t}$

Where $\quad C S_{-} H$

$T W_{-} B$, and $B G_{-} B$ represent the tea brands

Dang \& Lantican (2011)

Monthly farm-gate

$\Delta y_{1 t}=\pi_{11}+\pi_{12} \Delta y_{1, t-1}+\pi_{13} \Delta y_{2, t-1}+\pi_{14} \Delta y_{1, t-2}$

price, processor price

$+\pi_{15} \Delta y_{2, t-2}+\delta_{1} e c_{t-1}+v_{1 t}$

and retail price

Lagged price for grown

$\Delta y_{2 t}=\pi_{21}+\pi_{22} \Delta y_{1, t-1}+\pi_{23} \Delta y_{2, t-1}+\pi_{24} \Delta y_{1, t-2}$

$+\pi_{25} \Delta y_{2, t-2}+\delta_{2} e c_{t-1}+v_{2 t}$

(VAR and VEC)

(VEC)

Dharmasena (2003)

(VAR)
Lagged tea price of $4 \quad \alpha_{i j}=1-\alpha_{i j}(1) B^{1}-\alpha_{i j}(2) B^{2}-\ldots \ldots-\alpha_{i j}(k) B^{k} ; i$

auction centres $=j$

$\alpha_{i j}=-\alpha_{i j}(1) B^{1}-\alpha_{i j}(2) B^{2}-\ldots \ldots-\alpha_{i j}(k) B^{k} ; i \neq j$

There are a number of studies that have used the above methods in water and related areas and these have provided successful models and prediction outcomes and such provide support for the use of the time series methods (Tularam \& Ilahee, 2008, 2010; Tularam \& Keeler, 2006; Tularam \& Krishna, 2009; 2015; Tularam \& Marchisella, 2014; Tularam \& Properjohn, 2011; Tularam \& Singh, 2009)

\section{Discussion}

Clearly the tea industry provides considerable economic, social and environmental benefits. Almost all major tea producing countries' economies have been supported by the tea industry over many decades, mainly by generating foreign exchange earnings and providing a sizable percentage of employment opportunities. Tea has also become a necessary item in social and formal gathering in many parts of the world, and is the basis on which social and business networks are developed.

The tea industry is confronted by several challenges. The impacts of climate change are considered to be a major concern for most tea producing countries. Extreme weather events such as floods, erratic rainfall, drought, frequent hail or frost, and increasing temperatures have all been reported to be adversely affecting tea production in recent years. Figures 4, 5 and 6 all show an inverse relationship between temperature and rainfall in some of the major tea growing areas in the Indian subcontinent.

The econometric analyses have shown that tea prices are increasingly volatile. ARIMA, VAR approaches, and data mining techniques utilising sensory assessment scores, have all been used to model tea prices. Two studies have used similar variables to model tea prices; Dharmasena (2003) and Hettiarachchi and Banneheka (2013) analysed the performance of tea prices using the historical prices of major tea auction centres in the world. However the econometric methods used to model prices are different in both studies. Dharmasena (2003) has analysed time series prices of the major six auction centres, with the exception of Chittagong (Bangladesh) which is included in the analysis undertaken by Hettiarachchi and Banneheka (2013). Dharmasena (2003) has modelled weekly auction prices over the 
period from December 1999 through to June 2002 (131 data points) compared to Hettiarachchi and Banneheka (2013) who have used monthly data over the period of January 1997 to May 2010 (160 data points). Forecast performance of each technique described in both studies has been compared. Dharmasena (2003) concluded that forecasting was relatively accurate using VAR for the Sri Lankan and Malawi markets analysed when using dollar converted data. However, in general, the random walk model has produced smaller forecast errors compared to the VAR model for most of the auction centres considered in the modelling.

Hettiarachchi and Banneheka (2013) have used both the ANN technique and time series regression in forecasting Colombo auction prices. They considered the prices of 7 major auction centres in the world including Colombo. ANN performed only slightly better $\left(R^{2}=96.84 \%\right)$ than the time series regression techniques $\left(R^{2}=92.89 \%\right)$. This was the sole study that has used the ANN technique.

Three studies have used regression techniques to model tea prices. In particular, Rahman (2007) used agricultural factors such as total harvest price, price of competing items, total cultivated extent, irrigated area and chemicals and fertilizer as explanatory variables in the modelling of tea production and price elasticities of supply. But due to lack of data, he was not able to include variables such as weather and technical changes in the modelling. Rahman's model explained $92 \%$ of explanatory variation. Aponsu and Jayasundara (2012) have used time as the explanatory variable. In their regression model, they concluded that the cubic regression is the most appropriate model $\left(\mathrm{R}^{2}=\right.$ 91.3\%). Although the $\mathrm{R}^{2}$ is high, there are still many more variables other than time that need to be accounted for.

Four studies have used VAR methods, some using the VEC with co-integration. All studies have used more than 3 different dynamic price series. In relation to the data points, Vickner and Davies (2002), Dang and Lantican (2011), Dharmasena (2003) and Viknesh (2011) have used 180 week time series span, 180 monthly, 133 weekly, and 241 monthly, respectively. In terms of agricultural variables, only one VAR model used elevation data.

In sum, tea price movements and tea price volatility have been examined using univariate and multivariate time series techniques in several studies. However, the univariate time series models include only lag terms in tea prices and do not consider interaction between variables. Hence, the use of univariate models excessively confines the analysis to a single variable, despite the many interactions affected in a system of tea pricing. Yet various endogenous variables such as price and production may also be linked with exogenous variables, including biophysical factors such as rainfall, temperature and relative humidity which may act as a system in price determination. The analysis of regularities of such data which are observational may also be useful in determining the theoretical relationship between the variables used in the modelling. The VAR techniques have the ability to model the non-structural relationship of tea price alongside other time series variables. Perhaps these could be weather variables and cross lagged terms from one series as potential drivers of dependent variables in other series. However, it is noted that production, prices and climate variables such as rainfall and temperature as a system have not yet been taken into account in the tea price modelling process. This appears to be a major gap in the existing studies. Therefore there is a need to extend the studies of tea price movements and tea price volatility to include the weather variables to help the tea industry adapt to its changing circumstances.

\section{Conclusions}

The objectives of this paper were to analyse the current status of the tea industry, its major challenges and to identify how future directions of tea price modelling studies can help support the tea industry to adapt to climate change, which has been a major challenge for most of the producing countries.

Our findings show that both production and consumption of tea show an increasing trend over recent decades; and in particular that tea consumption has increased by a significant percentage in major tea producing countries such as China and India. This may be due to the high population growth levels in these countries and their consumption habits related to the socializing and health benefits identified by health agencies. Out of a total of 35 tea producing countries, China, India, Kenya and Sri Lanka are the largest tea producers. It was noted that Sri Lanka is the second largest exporter of tea, followed by Kenya. The tea industry has become a key player in most of the tea producing countries' economies by generating significant foreign exchange earnings and providing substantial employment opportunities.

Several challenges confront the tea industry. These challenges include the limited land area available for production expansion, increased competition from other beverages, scarcity of labour and climate change, which all impact on production and profitability. Climate change is a major challenge confronting tea producing countries, in particular Sri Lanka. Climate change concerns have led to the formation of the FAO's Intergovernmental Group on Tea, which aims to identify appropriate and effective climate adaptation measures through modelling and impact assessment. Erratic rainfall and increasing temperatures have been reported as adverse climate effects. Changes in extreme 
weather variables and the movement and volatilities in tea prices have been increasingly important in determining the association of weather variables and tea price movements. This can be done using appropriate methods to investigate the dynamic nature of the relationships between variables in the tea pricing system. Weather variables and other endogenous variables which effect tea prices in a changing climate may help provide more accurate forecasts. In addition, the model may provide information relating to adaptation options to deal with climate change.

The analysis of tea price modelling showed that various time series techniques have been used. Whilst ARIMA and cubic regression models have shown good predictive performance, in comparison VAR models have provided improved predictive capability for non-stationary tea prices. The VAR model appears to be the more appropriate method for modelling tea prices by incorporating a group of interacting time series variables in order to explain the dynamic relationships among these time series in the system. This framework can include other variables such as weather variables to quantify the likely impacts of climate change as noted.

\section{References}

Alkan, I., Koprulu, O., \& Alkan, B. (2009). Latest advances in world tea production and trade, Turkey's aspect. World Journal of Agricultural Sciences, 5(3), 345-349.

Aponsu, G. M. L. M., \& Jayasundara, D. D. M. (2012). Time Fluctuation Models to Forecast Tea Production, Prices and Exports in Sri Lanka. Paper presented at the 13th Annual Research Symposium, Faculty of Graduate Studies, University of Kelaniya, Sri Lanka.

Beenstock, M., \& Bhansali, R. J. (1980). Analysis of cocoa price series by autoregressive model fitting techniques. Journal of Agricultural Economics, 31(2), 237-242. http://dx.doi.org/10.1111/j.1477-9552.1980.tb01511.x

Blowfield, M. (2003). Ethical supply chains in the cocoa, coffee and tea industries. Greener Management International, 43, 14-24. http://dx.doi.org/http://dx.doi.org/10.9774/GLEAF.3062.2003.au.00004

Box, G. E. P., Jenkins, G. M., \& Reinsel, G. C. (2009). Time Series Analysis Forecasting and Control (3rd ed.). Pearson Education, Inc.

Broster, J. (1938). Elasticities of Demand for Tea and Price-Fixing Policy. Review of economic studies, 6, 165-176.

Brouder, A. M., Billing, S., \& Uren, S. (2013). The future of tea: A hero crop for 2030: Forum for the future.

Central Bank of Sri Lanka. (1992). Annual Report. Colombo, Sri Lanka.

Central Bank of Sri Lanka. (2013). Annual Report. Colombo, Sri Lanka: Retrieved from http://www.cbsl.gov.lk/pics_n_docs/10_pub/_docs/statistics/other/econ_\&_ss_2013_e.pdf

Dang, N. V., \& Lantican, F. A. (2011). Vertical integration of tea markets in Vietnam. ISSAAS, 17(1), 208-222.

de Godoy, R. C. B., Deliza, R., Gheno, L. B., Licodiedoff, S., Frizon, C. N. T., Ribani, R. H., \& dos Santos, G. G. (2013). Consumer perceptions, attitudes and acceptance of new and traditional mate tea products. Food Research International, 53(2), 801-807. http://dx.doi.org/10.1016/j.foodres.2013.02.054

Deaton, A., \& Laroque, G. (1992). On the behaviour of commodity prices. Review of economic studies, 59, 1-23. http://dx.doi.org/10.2307/2297923

Dharmasena, K. A. S. D. B. (2003). International black tea market integration and price discovery (Master's thesis), Texas A\&M University. Retrieved from http://hdl.handle.net/1969.1/273

Dutta, M. (1965). Measuring the role of price in international trade: some further tests. Econometrica, 3(33), 600-607. http://dx.doi.org/10.2307/1911755

Ethical Tea Partnership. (2012). An Industry in Transition: The future of the plantation community. A multi-stakeholder discussion. Retrieved $21^{\text {st }}$ Jan 2015, from http://www.ethicalteapartnerships.org/

Euromonitor International. (2014). Dual opportunities for tea in retail and foodservice. Retrived from http://blog.euromonitor.com/2013/08/dual-opportunities-for-tea-in-retail-and-foodservice.html

FAOSTAT. (2014). Retrived June, 2014, from www.fao.org

Fernando, H. C., Tissera, W. M. R., \& Athauda, R. I. (2008). Gaining Insights to the Tea Industry of Sri Lanka using Data Mining. Paper presented at the International MultiConference of Engineers and Computer Scientists, Hong Kong. 
Ganewatta, G., Waschik, R., Jayasuriya, S., \& Edwards, G. (2005). Moving up the processing ladder in primary product exports: Sri Lanka's "value-added" tea industry. Agricultural Economics, 33(3), 341-350. http://dx.doi.org/10.1111/j.1574-0864.2005.00073.x

Gramza-Michalowska, A. (2014). Caffeine in tea Camellia sinensis - content, absorption, benefits and risks of consumption. Journal of Nutrition Health \& Aging, 18(2), 143-149.

Groosman, M. (2011). Sector overview Tea: The Sustainable Trade Initiative.

Hettiarachchi, H. A. C. K., \& Banneheka, B. M. S. G. (2013). Time series regression and artificial neural network approaches for forecasting unit price of tea at Colombo auction. Journal of National Science Foundation Sri Lanka, 41(1), 35-40.

Hicks, A. (2001). Review of global tea production and the impact on industry of the Asian economic situation. Retrieved from http://www.journal.au.edu/au_techno/2001/oct2001/article4.pdf

Hicks, A. (2009). Current status and future development of global tea production and tea products. AU.JT, 12(4), 251-264. Retrieved from http://www.teainstitutemfu.com/ducument/d11.pdf

Hilal, Y., \& Engelhardt, U. (2007). Characterisation of white tea - Comparison to green and black tea. Journal Fur Verbraucherschutz Und Lebensmittelsicherheit-Journal of Consumer Protection and Food Safety, 2(4), 414-421. http://dx.doi.org/10.1007/s00003-007-0250-3

Illukpitiya, P., Shanmugaratnam, N., \& Kjosavik, D. J. (2004). Tea agroecosystems in the Uva Highlands of Sri Lanka. Mountain Research and Development, 24(1), 52-59. http://dx.doi.org/10.1659/0276-4741(2004)024[0052:TAITUH]2.0.CO;2

Khan, N., \& Mukhtar, H. (2013). Tea and Health: Studies in Humans. Current Pharmaceutical Design, 19(34), 6141-6147.

Kingsolver, A. E. (2010). "Like a Frog in a Well": Young People's Views of the Future Expressed in Two Collaborative Research Projects in Sri Lanka. Human Organization, 69(1), 1-9.

Klonaris, S. (2011). A demand analysis for the tea market. Food and Agriculture Organization: Intergovernmental Group on Tea, Food and Agriculture Organization.

Kondo, M., Kita, K., \& Yokota, H. (2004). Effects of tea leaf waste of green tea, oolong tea, and black tea addition on sudangrass silage quality and in vitro gas production. Journal of the Science of Food and Agriculture, 84(7), 721-727. http://dx.doi.org/10.1002/jsfa. 1718

Krishnarani, S. D. (2013). Time series outlier analysis of tea price data American Journal of Theoretical and Applied Statistics, 2(1), 1-6. http://dx.doi.org/10.11648/j.ajtas.20130201.11

Lambert, J. D. (2013). Does tea prevent cancer? Evidence from laboratory and human intervention studies. American Journal of Clinical Nutrition, 98(6), 1667S-1675S. http://dx.doi.org/10.3945/ajen.113.059352

Li, S, Wu, X, Xue, H, Gu, B. , Cheng, H, Zeng, J, . . Chang, J. (2011). Quantifying carbon storage for tea plantations in China. Agriculture Ecosystems \& Environment, 141(3-4), 390-398. http://dx.doi.org/10.1016/j.agee.2011.04.003

Louni, H. (2008). Outlier detection in ARMA models. Journal of time series analysis, 29(6), 1057-1065.

Madamombe, G. M., Taylor, N. J., \& Tesfamariam, E. (2013). Yield Decline in Vegetatively Propagated Tea (Camellia sinensis (L.) O. Kuntze) under Continuous Mechanical Harvesting. Ii All Africa Horticulture Congress, 1007, 857-862.

Majumder, B. A., Bera, B., \& Rajan, A. (2012). Tea Statistics: Global Scenario. Inc.J.Tea.Sci., 8(1), 121-124.

Monroy, L., Mulinge, W., \& Witwer, M. (2013). Analysis of incentives and disincentives for tea in Kenya. Technical notes series. Retrived from http://www.fao.org/mafap

Mwaura, F., \& Muku, O. (2007). Tea farming enterprise contribution to smallholders' well being in kenya. AAAE Conference Proceedings 307-313.

Nasir, T., \& Shamsuddoha, M. (2011). Tea production, consumption and exports in global and Bangladeshi perspective International Journal of Education Research and Technology, 2(1), 68-73. 
Neilson, J., \& Pritchard, B. (2010). Fairness and ethicality in their place: the regional dynamics of fair trade and ethical sourcing agendas in the plantation districts of South India. Environment and Planning, 42, 1833-1851. http://dx.doi.org/10.1068/a4260

Pajankar, V. D., \& Thakare, A. B. (2009). Consumption and export of tea in India. International Journal of Agricultural and Statistical Sciences, 5(1), 65-71.

Paul, S. K. (2008). Predictability of price of tea from sensory assessments and biochemical information using data-mining techniques. Journal of the Science of Food and Agriculture, 88(8), 1354-1362. http://dx.doi.org/10.1002/jsfa.3223

Paul, S., Wachira, F. N., Powell, W., \& Waugh, R. (1997). Diversity and genetic differentiation among populations of Indian and Kenyan tea (Camellia sinensis (L.) O. Kuntze) revealed by AFLP markers. Theor Appl Genet, 94, 255-263.

Peera, N. (1971). Measuring price sensitivity of indian tea exports - comment. Econometrica, 39(1), 177-178. http://dx.doi.org/10.2307/1909148

Rahman, M. L. (2007). Impact of price and other factors on tea in Bangladesh: Sources of variation and disparity over division. BRAC University Journal, 4(1), 9-11.

Raynolds, L. T., \& Ngcwangu, S. U. (2010). Fair Trade Rooibos tea: Connecting South African producers and American consumer markets. Geoforum, 41, 74-83. http://dx.doi.org/10.1016/j.geoforum.2009.02.004

Rogers, M. (2007). The story of tea: A cultural history and drinking guide. Library Journal, 132(16), 90-90.

Roy, S. (2011). Historical review of growth of tea industries in India: A study of Assam Tea. Paper presented at the International Conference on Social Science and Humanity, Singapore. Retrieved $20^{\text {th }}$ Jan 2015, from http://www.ipedr.com/vol5/no1/35-H00082.pdf

Sapsford, D., \& Varoufakis, Y. (1987). An ARIMA analysis of tea prices. Journal of Agricultural Economics, 38(2), 329-334. http://dx.doi.org/10.1111/j.1477-9552.1987.tb01051.x

Sivaram, B. (2000). Labour Management and Planning. In B. Sivaram (Ed.), Plantation Management in the New Millennium. National Institute of Plantation Management.

Tea Board of India. (2014). Retrieved from http://www.teaboard.gov.in

Tea Board of Kenya. (2012). Retrieved from http://www.teaboard.or.ke

Tounekti, T., Joubert, E., Hernandez, I., \& Munne-Bosch, S. (2013). Improving the Polyphenol Content of Tea. Critical Reviews in Plant Sciences, 32(3), 192-215. http://dx.doi.org/10.1080/07352689.2012.747384

Tularam, G. A., \& Hassan O. M. (In press) Water availability and food security - impact on people's movement and migration in sub-Saharan Africa (SSA). Springer Publications.

Tularam, G. A., \& Illahee, M. (2008). Exponential Smoothing Method of Base Flow Separation and Its Impact on Continuous Loss Estimates. American Journal of Environmental Sciences, 4, 136-144.

Tularam, G. A., \& Illahee, M. (2010). Time series analysis of rainfall and temperature interactions in coastal catchments. Journal of Mathematics and Statistics, 6, 372-380.

Tularam, G. A., \& Keeler, H. P. (2006). The study of coastal groundwater depth and salinity variation using time-series analysis. Environmental Impact Assessment Review, 26, 633-642.

Tularam, G. A., \& Krishna, M. (2009). Long term consequences of groundwater pumping in Australia: A review of impacts around the globe. Journal of Applied Sciences in Environmental Sanitation, 151-166.

Tularam, G. A., \& Marchisella, P. (2014). Water Scarcity in Asia and its Long Term Water and Border Security Implications for Australia, International Practices for Protecting Water and Wastewater Infrastructure. Springer Publications.

Tularam, G. A., \& Murali, K. K. (2015). Water Security Problems in Asia and Longer Term Implications for Australia. Springer Publications.

Tularam, G. A., \& Properjohn, M. (2011). An investigation into water distribution network security: Risk and implications. Security Journal, 4, 1057-1066.

Tularam, G. A., \& Singh, R. (2009). Estuary, river and surrounding groundwater quality deterioration associated with tidal intrusion. Journal of Applied Sciences in Environmental Sanitation, 4, 141-150. 
Van der Wal, S. (2008). Sustainability issues in the tea sector: A comparative analysis of six leading producing countries. StichtingOnderzoekMultinationaleOndernemingen. Retrieved $20^{\text {th }}$ Jan 2015, from $\mathrm{http}: / / \mathrm{ssrn} . \mathrm{com} / \mathrm{abstract}=1660434$

Vernarelli, J. A., \& Lambert, J. D. (2013). Tea consumption is inversely associated with weight status and other markers for metabolic syndrome in US adults. European Journal of Nutrition, 52(3), 1039-1048. http://dx.doi.org/10.1007/s00394-012-0410-9

Vickner, S. S., \& Davies, S. P. (2002). Estimating strategic price response using cointegration analysis: The case of the domestic black and herbal tea industries. Agribusiness, 18(2), 131-144.

Viknesh, N. (2011). Forecasting Sri Lankan black tea prices (Master's thesis), Postgraduate Institute of Science, University of Peradeniya, Sri Lanka. Retrieved 21 ${ }^{\text {st }}$ Jan 2015, from http://www.dlib.pdn.ac.lk/archive/handle123456789/2583

Vuong, Q. V. (2014). Epidemiological Evidence Linking Tea Consumption to Human Health: A Review. Critical Reviews in Food Science and Nutrition, 54(4), 523-536. http://dx.doi.org/10.1080/10408398.2011.594184

Wachira, F., \& Kamunya, S. M. (2005). Kenyan teas are rich in antioxidents. Tea 2005, 26(2).

Wijeratne, M. A. (1996). Vulnerability of Sri Lanka tea production to global climate change.Water, Air and Soil Pollution, 92, 87-94.

Wijeratne, M. A., Anandacoomaraswamy, A., Amarathunga, M. K. S. L. D., Ratnasiri, J., Basnayake, B. R. S. B., \& Kalra, N. (2007). Assessment of impact of climate change on productivity of tea (Camellia sinensis L.) plantations in Sri Lanka. J. Natn. Sci. Foundation Sri Lanka, 35(2),119-126.

World Tea News. (2014). Tea: The Future is Green and Herbal - Global Markets, Competitors and Opportunities 2013-2018 Analysis and Forecasts. Retrieved http://www.reportlinker.com/p01907817/Tea-The-Future-is-Green-and-Herbal---Global-Markets-Competitors-a nd-Opportunities---2013-2018-Analysis-and-Forecasts

Xue, H., Ren, X. Y., Li, S. Y., Wu, X., Cheng, H., Xu, B., . . Chang, J. (2013). Assessment of private economic benefits and positive environmental externalities of tea plantation in China. Environmental Monitoring and Assessment, 185(10), 8501-8516. http://dx.doi.org/10.1007/s10661-013-3191-6

Yang, C. S., Lambert, J. D., \& Sang, S. M. (2009). Antioxidative and anti-carcinogenic activities of tea polyphenols. Archives of Toxicology, 83(1), 11-21. http://dx.doi.org/10.1007/s00204-008-0372-0 